\title{
Revised classification of anonymous mycobacteria
}

\author{
C. H. COLLINS \\ From the Bacteriological Laboratory (P.H.L.S.), County Hall, London
}

SYNOPSIS Anonymous mycobacteria can be classified into 10 groups by methods and media usually available in the clinical bacteriology department. These groups are given names which reflect the species they are thought to contain or an important cultural characteristic.

Three methods for the laboratory classification of mycobacteria have been proposed. Runyon (1955) used pigment production and rate of growth to define four groups (numbered 1 to 4). Collins (1962) employed growth at $20^{\circ} \mathrm{C}$. and $44^{\circ} \mathrm{C}$., resistance to thiosemicarbazone, and growth in a synthetic medium to describe four similar groups (assemblies A to D). Marks and Richards (1963) used morphological, colonial, and cultural characteristics, growth at $25^{\circ} \mathrm{C}$. and $42^{\circ} \mathrm{C}$., and drug resistance to identify seven groups (numbered 1 to 7 ) of pathogenic mycobacteria.

Each of these systems has disadvantages. Those of Runyon and Collins define only four groups, three of which are heterogenous. That of Marks and Richards does not include some mycobacteria commonly found in clinical material. Moreover, the tests employed by Runyon, and to some extent by Marks and Richards, are subjective and there is some difficulty in defining some of the groups of Marks and Richards on purely bacteriological grounds.

The need for a revised clinical laboratory classification led us to re-examine the 199 strains studied in 1962 and to test an additional 121 strains. Forty species and unnamed strains from the National Collection of Type Cultures were also examined. Only those tests which can easily be performed in the clinical laboratory were used. For this reason the Received for publication 2 February 1966

Mycobacterium

Author

Mycobacterium phlei

Mycobacterium smegmatis

Mycobacterium fortuitum

Mycobacterium kansasii

Mycobacterium acapulcensis

Mycobacterium gordonae

Mycobacterium flavescens

Mycobacterium runyonii

Mycobacterium peregrinum

Mycobacterium avium

Mycobacterium xenopei

Mycobacterium spp. carbohydrate and organic acid utilization tests of Gordon and Smith (1953), Bojalil and Cerbón (1961), and Bojalil, Cerbón, and Trujillo (1962) were not used. These tests also take too long and the results are sometimes difficult to interpret.

\section{MATERIALS AND METHODS}

ORGANISMS The following mycobacteria were examined: 279 strains of anonymous mycobacteria (113 were isolated by the author, 166 were from other laboratories). Forty-one strains from the Tuberculosis Reference Laboratory (T.R.L.) 12 of which were photochromogens: five were Mycobacterium scrofulaceum (Prissick and Masson, 1956) four of them described by Marsden and Hyde (1962) and one other strain, seven were Mycobacterium xenopei (Schwabacher, 1959; Marks and Schwabacher, 1965), and 17 were Mycobacterium avium. Forty strains from the National Collection of Type Cultures included new species described by Bojalil et al. (1962) and are tabulated below.

Cultures were maintained on Lowenstein-Jensen medium and subcultured at approximately three-monthly intervals. Suspensions for inoculating other media were prepared by adding a loopful of culture ('one matchhead') to a small screw-capped bottle containing $1 \mathrm{ml}$. of sterile distilled water and a few glass beads. Vigorous shaking for $\mathbf{2} \mathrm{min}$. usually gave a satisfactory suspension. Solid media were inoculated with one $3 \mathrm{~mm}$. loopful, drawn edgewise from the suspension and streaked from top to bottom of the slope.
N.C.T.C. No.
Lehmann and Neumann

(Trevisan) Lehmann and Neumann

Cruz

Hauduroy

Bojalil, Cerbon, and Trujillo (1962)

Bojalil, Cerbon, and Trujillo (1962)

Bojalil, Cerbon, and Trujillo (1962)

Bojalil, Cerbon, and Trujillo (1962)

Bojalil, Cerbon, and Trujillo (1962)

Chester

Schwabacher (1959)
$525,8151,8156,10008,10026$

$333,523,8150,8152,8159,10265$

946, 1542, 2006, 2291, 2891, 3631, 8573, 8697

10268

10270

10267

10271

10264

$8551,8552,8553,8559,8562$

10042

$358,8160,8645,8646,8656,8657,9822,9847$ 
GROWTH TEMPERATURES Duplicate cultures of Lowenstein-Jensen medium were incubated at these temperatures: $20^{\circ} \mathrm{C}$. (lagged water bath in a domestic refrigerator); $25^{\circ} \mathrm{C}$. and $28^{\circ} \mathrm{C}$. (water baths on laboratory bench); $44^{\circ} \mathrm{C}$. (water bath in laboratory hot room). These cultures were examined for growth daily for seven days and weekly for four weeks. Organisms growing at $20^{\circ}$ to $37^{\circ} \mathrm{C}$. were recorded as mesophiles; those growing at $44^{\circ} \mathrm{C}$. as thermophiles.

'LIGHT' AND 'DARK' CULTURES Two Lowenstein-Jensen cultures were incubated at $37^{\circ} \mathrm{C}$. in an incubator fitted with a 6 watt fluorescent lamp (Collins and Massey, 1963). These were designated 'light' cultures and were examined daily for seven days and weekly for four weeks for growth. Two other cultures were incubated at $37^{\circ} \mathrm{C}$ in a lightproof box. These, called the 'dark' cultures, were examined after four weeks. Pigment formation was recorded at four weeks as: ( $a$ ) 'light' culture showing yellow pigment, 'dark' culture showing no pigment, photochromogen; $(b)$ both cultures showing pronounced yellow pigment or 'dark' culture showing yellow and 'light' culture an orange pigment, scotochromogen; $(c)$ either or both cultures showing a faint, feeble, or doubtful yellow pigment, parvochromogen; (d) no pigment in either culture, non-chromogen.

GROWTH IN SYNTHETIC MEDIUM The ' $N$ ' medium (Collins, 1962) was used, i.e., $\mathrm{NaCl} 1.0$ g.: $\mathrm{MgSO}_{4}$. $7 \mathrm{H}_{2} \mathrm{O}$ 0.2 g.; $\mathrm{KH}_{2} \mathrm{PO}_{4} 0.5$ g.; $\mathrm{Na}_{2} \mathrm{HPO}_{4} 3.0$ g. $\left(\mathrm{NH}_{4}\right) 2 \mathrm{SO}_{4} 10$ g.;

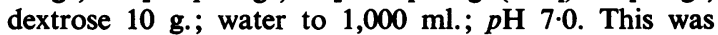
bottled in $3 \mathrm{ml}$. amounts and autoclaved. Duplicate tubes of the medium were inoculated with a straight wire from the distilled water suspension. Cultures were incubated for four days only. If growth occurred subcultures were made into the same medium with a straight wire and the identity of the growth checked by microscopy and culture on Lowenstein-Jensen medium. Only subcultivable growth was recorded as positive ('Npositive'). Good correlation had previously been demonstrated between growth in this medium and 'rapid growth', i.e., growth in three days, on LowensteinJensen medium, particularly if the latter was observed by the naked eye at $25^{\circ} \mathrm{C}$.

Organisms giving subcultivable growth in ' $N$ ' medium in four days were therefore arbitrarily designated 'rapid growers' and other mycobacteria as 'slow growers'.

ARYL SULPHASE TEST Of a $3.2 \%$ aqueous Seitz-filtered solution of phenolphthalein disulphate (L. Light \& Co.), $20 \mathrm{ml}$. was added to $1,000 \mathrm{ml}$. of Dubos and Davies (1946) Tween albumin medium to give a final concentration of $M / 1,000$ and the mixture distributed aseptically in $3 \mathrm{ml}$. amounts. Duplicate tubes were heavily inoculated from the primary Lowenstein-Jensen culture and incubated for 21 days. Cultures were tested for free phenolphthalein by adding $0.5 \mathrm{ml}$. of concentrated S.G. $0 \cdot 880$ ammonia solution. The results were recorded as deep pink or purple, strongly positive $(+++)$, pink, positive $(++)$, pale pink, weak positive $(+)$, or doubtful or no colour, negative (-).

CATALASE PRODUCTION Of a mixture of equal parts of $1 \%$ Tween 80 and 20 vol. hydrogen peroxide $5 \mathrm{ml}$. was added to the 28 -day $37^{\circ} \mathrm{C}$. Lowenstein-Jensen cultures. The slopes were placed in a horizontal position for 5 min. and then placed upright. Catalase production was read as effervescence of more than $10 \mathrm{~mm}$. strongly positive $(+++)$; $5-10 \mathrm{~mm}$., positive $(++) ; 1-5 \mathrm{~mm}$., weak positive $(+)$; less than $1 \mathrm{~mm}$., negative.

DRUG SENSITIVITY TESTS Strains were tested by the usual methods (Collins and Massey, 1963) against streptomycin, I.N.A.H., P.A.S., ethionamide, cycloserine, viomycin, and thiosemicarbazone.

MORPHOLOGY This was observed at various stages of the growth on Lowenstein-Jensen medium by ZiehlNeelsen staining.

\section{RESULTS}

Growth at $20^{\circ}, 25^{\circ}$, and $44^{\circ} \mathrm{C}$, growth in ' $\mathrm{N}$ ' medium ('rapid' or 'slow' growth), pigmentation, catalase and sulphatase reactions, sensitivity to thiosemicarbazone, ethionamide, and isoniazid allowed the 360 strains to be separated into 10 groups. Growth at $28^{\circ} \mathrm{C}$. was of limited value. Sensitivity to cycloserine, viomycin, and streptomycin was too variable to be useful. All strains were resistant to at least $1.0 \mu \mathrm{g}$. per ml. of P.A.S.

The properties of the members of the groups are shown in Table I.

\section{GROUPS OF MYCOBACTERIA}

PHLEI-SMEGMATIS GROUP (12 STRAINS) Five strains of $M$. phlei, six strains of $M$. smegmatis, and one wild strain fell into the group of rapidly growing thermophiles. Pigmentation was variable. Culture at $52^{\circ} \mathrm{C}$. distinguishes $M$. phlei, which grows, from M. smegmatis, which does not. Carbohydrate and organic acid utilization tests can also be used to distinguish these species.

ACAPULCENSIS GROUP (21 STRAINS) M. acapulcensis, three unnamed N.C.T.C. strains $(358,8160,8645)$, and 17 wild strains comprised this group of rapidly growing mesophilic scotochromogens.

FORTUITUM GROUP (113 STRAINS) $M$. fortuitum (eight strains), M. runyonii, M. peregrinum, and 103 wild strains were placed in this group of rapidly growing mesophilic non-chromogens. The named species can be distinguished by carbohydrate and organic acid utilization tests.

KANSASII GROUP (73 StRAINS) $M$. kansasii, 12 T.R.L., and 60 wild strains made up this group of slow-growing mesophilic photochromogens. These organisms are sensitive to low concentrations of 
TABLE I

PROPERTIES OF 10 GROUPS OF MYCOBACTERIA

\begin{tabular}{|c|c|c|c|c|c|c|c|c|c|c|c|c|c|}
\hline \multirow[b]{2}{*}{ Group } & \multirow[b]{2}{*}{ Short Definition } & \multicolumn{3}{|c|}{ Growth at } & \multicolumn{6}{|c|}{ Growth in } & \multicolumn{3}{|c|}{ Other Classifications } \\
\hline & & $20^{\circ} \mathrm{C}$. & $25^{\circ} \mathrm{C}$. & $44^{\circ} \mathrm{C}$ & $\begin{array}{l}N . \\
\text { Medium }\end{array}$ & $\begin{array}{c}20 \mu g . \\
\text { T.S.C. }\end{array}$ & $\begin{array}{c}6 \mu g . \\
\text { Eth. }\end{array}$ & $\begin{array}{l}0.4 \mu g . \\
I . N . A .\end{array}$ & $\begin{array}{l}\text { Cata- } \\
\text { lase }^{2}\end{array}$ & $\begin{array}{l}\text { Sul- } \\
\text { phatase }\end{array}$ & Runyon & Collins & $\begin{array}{l}\text { Marks } \\
\text { and } \\
\text { Richards }\end{array}$ \\
\hline Phlei-Smegmatis & $\begin{array}{l}\text { Rapidly growing } \\
\text { thermophiles, } \\
\text { pigment variable }\end{array}$ & + & + & + & + & + & + & + & ++ & ++ & IV & $\mathbf{D}$ & 一 \\
\hline Acapulcensis & $\begin{array}{l}\text { Rapidly growing, } \\
\text { mesophilic, } \\
\text { scotochromogens }\end{array}$ & + & + & - & + & + & + & + & $+t+$ & ++ & IV & $\mathbf{D}$ & - \\
\hline Fortuitum & $\begin{array}{l}\text { Rapidly growing, } \\
\text { mesophilic, } \\
\text { non-chromogens }\end{array}$ & + & + & - & + & + & + & + & $++t$ & $+t+$ & IV & $\mathbf{D}$ & 6 \\
\hline Kansasii & $\begin{array}{l}\text { Slow growing, } \\
\text { mesophilic, } \\
\text { photochromogens }\end{array}$ & 一 & + & 一 & - & 一 & 一 & + & $++t$ & $\begin{array}{l}+ \\
\text { or - }\end{array}$ & $\mathbf{I}$ & $\mathbf{A}$ & 1 \\
\hline Scrofulaceum & $\begin{array}{l}\text { Slow growing, } \\
\text { mesophilic, } \\
\text { parvo- or } \\
\text { scotochromogens }\end{array}$ & - & + & 一 & - & - & 一 & + & + & - & $\begin{array}{l}\text { II } \\
\text { or } \\
\text { III }\end{array}$ & 一 & 2 \\
\hline Gordonae & $\begin{array}{l}\text { Slow growing, } \\
\text { mesophilic, } \\
\text { scotochromogens }\end{array}$ & $\mathbf{V}^{\mathbf{1}}$ & + & - & - & + & + & + & +++ & $\begin{array}{l}+ \\
\text { or - }\end{array}$ & II & $\mathbf{B}$ & 一 \\
\hline Parvochromogens & $\begin{array}{l}\text { Slow growing, } \\
\text { mesophilic, } \\
\text { parvochromogens }\end{array}$ & - & + & 一 & - & + & + & + & + & $\begin{array}{l}+ \\
\text { or - }\end{array}$ & III & $\mathbf{B}$ & - \\
\hline Non-chromogens & $\begin{array}{l}\text { Slow growing, } \\
\text { mesophilic, } \\
\text { non-chromogens }\end{array}$ & $\mathbf{V}$ & + & - & 一 & + & + & + & $\begin{array}{l}\text { Most } \\
\text { strains } \\
+\end{array}$ & $\begin{array}{l}\text { Most } \\
\text { strains } \\
+\end{array}$ & III & $\mathbf{B}$ & 5 \\
\hline Xenopei & $\begin{array}{l}\text { Slow growing, } \\
\text { thermophilic, } \\
\text { parvochromogens }\end{array}$ & 一 & -4 & + & 一 & + & 一 & 一 & - & ++ & III & $\mathbf{C}$ & 3 \\
\hline Avium & $\begin{array}{l}\text { Slow growing, } \\
\text { thermophilic, } \\
\text { non-chromogens }\end{array}$ & 一 & + & + & - & + & + & + & - & $\begin{array}{l}+ \\
\text { or - }\end{array}$ & III & C & 4 \\
\hline M. tuberculosis & $\begin{array}{l}\text { Slow growing, } \\
\text { mesophilic, } \\
\text { non-chromogens }\end{array}$ & - & 一 & 一 & 一 & - & 一 & - & ++ & - & 一 & 一 & - \\
\hline
\end{tabular}

${ }^{1} \mathrm{~V}=$ growth, if any, is poor.

${ }^{2}$ Catalase +++ strongly positive, ++ positive, + weak positive - negative.

${ }^{3}$ Sulphatase +++ strongly positive, ++ positive, + weak positive - negative or doubtful.

Grows at $28^{\circ} \mathrm{C}$.

thiosemicarbazone and ethionamide. They have a distinctive morphology: the bacilli are long (up to $10 \mu$ ) slender, often fusiform, and show beading or banding.

SCROFULACEUM GROUP (11 STRAINS) M. scrofulaceum (five T.R.L. strains) and six wild strains made up this group of slow-growing mesophilic parvochromogens. These are intermediate in some properties between the Kansasii and Gordonae groups: they are not as sensitive as the former but are more sensitive than the latter to thiosemicarbazone; the pigment is usually less marked than that of the true scotochromogens and does not deepen to orange on continued exposure to light. $M$. scrofulaceum is considered by Bojalil et al. (1962) to be $M$. marianum but this name is not used here because of possible confusion with $M$. marinum (M. balnei).

GORDONAE GROUP (44 STRAINS) $M$. gordonae, $M$. flavescens, two unnamed N.C.T.C. strains (8646,
9822), and 40 wild strains were placed in the group of slow-growing mesophilic scotochromogens. $M$. gordonae and $M$. flavescens can be distinguished by carbohydrate and organic acid utilization tests.

PARVOCHROMOGENS (12 STRAINS) No named species or unnamed N.C.T.C. strains fell into this group of slow-growing mesophilic parvochromogens. The production of a pale yellow but distinct pigment and failure to grow at $20^{\circ}$ and $44^{\circ} \mathrm{C}$. is peculiar to this group.

NON-CHROMOGENS (28 STRAINS) No named species but four unnamed N.C.T.C. strains $(8656,9847$, 9849,8657 ) and 24 wild strains comprise this group of slow-growing mesophilic non-chromogens. The properties of these organisms are variable but the complete absence of pigment separates them from the parvochromogens.

XENOPEI GROUP (18 STRAINS) $M$. xenopei, seven T.R.L., and 10 wild strains made up this group of 
slow-growing, thermophilic, isoniazid-sensitive parvochromogens, the most important characteristic of which is relative sensitivity to isoniazid. With rare exceptions, other anonymous mycobacteria are resistant to much higher concentrations of this drug. Marks (1964) has equated the isoniziad-sensitive thermophiles' of the classification of Marks and Richards with $M$. xenopei. These organisms also have a characteristic morphology: they are long $(8$ to $10 \mu)$ and may resemble the Kansasii group of organisms in their general appearance. Pigment is pale yellow but distinct, and the catalase test is negative. They are reluctant to grow at $25^{\circ} \mathrm{C}$. but usually grow at $28^{\circ} \mathrm{C}$. in four weeks.

AVIUM GROUP (28 STRAINS) Twenty-two strains of M. avium (five N.C.T.C. and 17 T.R.L. strains) and six wild strains belonged to the group of slowgrowing, thermophilic, isoniazid resistant nonchromogens. Like the Xenopei group these grow well at $44^{\circ} \mathrm{C}$., but are resistant to higher concentrations of isoniazid and fail to produce pigment. The catalase test is negative.

\section{DISCUSSION}

Positive identification of most species of mycobacteria is difficult even with the carbohydrate and organic acid utilization tests mentioned above. With the ordinary tests and media available in the clinical laboratory it is not possible to give specific names with any degree of certainty, except to $M$. tuberculosis. The series of tests used in this investigation does, however, enable an anonymous mycobacterium to be placed in one of 10 informal groups which have been given names reflecting the species they are thought to contain, if these are known, and a cultural characteristic if they are not.

In this laboratory pigmentation was discarded as an aid to classification in 1962 because it was thought to be too subjective. It was difficult to place some organisms in one of the Runyon groups as rapid growth, also subjective, apparently takes precedence over pigmentation characteristics in the Runyon system. Some doubts were also felt about the definition of the 'non-photochromogens' and the formation of pigment by photochromogens was known to depend upon the duration of exposure to light and the age of the culture when exposed. The introduction of the continuously illuminated incubator and the definition of another kind of pigmentation, that of the parvochromogen (Latin, parvus, little), overcomes a major obstacle in the use of pigmentation for this purpose.

In Runyon's scheme the organisms in the Avium,
Xenopei, parvochromogen and non-chromogen groups would qualify as non-photochromogens (group III). The avium and xenopei groups, however, grow at $44^{\circ} \mathrm{C}$. while the parvochromogens and nonchromogens do not. Since most of the organisms in the avium and xenopei groups were considered to cause human disease and very few suspected pathogens were found among the parvochromogens and non-chromogens, a useful separation is obtained by this test.

The important characteristic of assembly $\mathrm{A}$ in the classification proposed by Collins (1962) was sensitivity to $10 \mathrm{mcg}$. per ml. of thiosemicarbazone. At that time no strains now placed in the Scrofulaceum group had been examined. When these strains were tested it was found that some were sensitive and some were resistant to this concentration. They were all sensitive to $20 \mu \mathrm{g}$. per ml., however, and inhibition of growth by this concentration of thiosemicarbazone is used to recognize both the Kansasii and Scrofulaceum groups which are then separated by their pigmentation and their catalase activity.

Rate of growth was also discarded in the writer's earlier classification because of the difficulty with some organisms in deciding when growth first appeared. Traditionally, 'rapid growers' grow in three days and 'slow growers' take six or more. In some of our strains growth on Lowenstein-Jensen medium was first noted at four or five days. As indicated above, this problem was solved in an arbitrary way by using subcultivable growth in four days in the synthetic medium to indicate rapid growth.

Morphological and colonial appearances are considered to be of limited value in placing mycobacteria in these groups. Only the Kansasii and Xenopei groups showed consistently distinctive microscopic appearance.

It is not possible to say, on bacteriological grounds, if an anonymous mycobacterium is pathogenic. The clinical appearance, presence of any other agent, and number of times the organism is isolated from the patient must be considered. Experience suggests that organisms in the Kansasii, Scrofulaceum, Xenopei, and Avium groups are likely to be pathogenic, but those in the Phlei-smegmatis, Acapulcensis, Gordonae, parvochromogen, and nonchromogen groups are not. $M$. fortuitum is a common saprophyte, often isolated from sputum on single occasions but some of the pathogens in the groups 6 and 7 of Marks and Richards resemble some of those in the Fortuitum group. There have been several reports of lung disease and subcutaneous abscesses associated with $M$. fortuitum. The most recent of these are by Dross, Abbatiello, Jenney, and Cohen (1964) and Beck (1965). 
The strains of $M$. tuberculosis isolated in this laboratory are recognized by their failure to grow at $25^{\circ} \mathrm{C}$. in three weeks, their sensitivity to paranitrobenzoic acid, and P.A.S. (except when the patient is known to have been treated with this drug), and their failure to produce pigment when exposed to light continuously during three week's incubation. In doubtful strains, the niacin test is used.

I am indebted to the Curator of the National Collection of Type Cultures, to Dr. J. Marks, Director of the Tuberculosis Reference Laboratory, and other bacteriologists who kindly supplied some of the cultures for this investigation.

\section{REFERENCES}

Beck, A. (1965). J. clin. Path., 18, 307.

Bojalil, L. F., and Cerbón, J. (1961). J. Bact., 81, 338.

-, Cerbón, J., and Trujillo, A. (1962). J. gen. Microbiol., 28, 333. Collins, C. H. (1962). Tubercle (Edinb.), 43, 292.

- , and Massey, M. L. (1963). In Progress in Medical Laboratory. Technique. edited by F. J. Baker, vol. 2, p. 82. Butterworth, London.

Dross, I. C., Abbatiello, A. A. Jenney, F. S. and Cohen, A. C. (1964) Amer. Rev. resp. Dis., 89, 923.

Gordon, R. E., and Smith, M. M. (1953). J. Bact., 66, 41.

Marks, J., and Richards, M. (1963). Mth. Bull. Minist. Hlth Lab. Serv., 21, 200.

, and Schwabacher, H. (1965). Brit. med. J., 1, 32.

Marsden, H. B., and Hyde, W. A. (1962). Lancet, 1, 249.

Prissick, F. H., and Masson, A. M. (1956). Canad.med. Ass. J.. 75, 798.

Runyon, E. H. (1955). Amer. Rev. Tuberc., 72, 866.

Schwabacher, H. (1959). J. Hyg. (Lond.), 57, 57. 